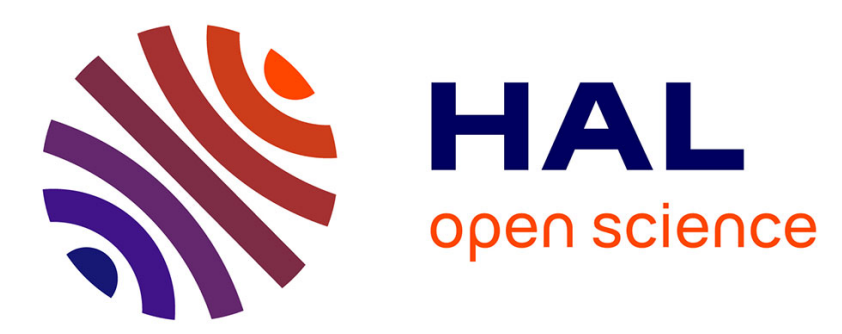

\title{
Extensional tectonics in the Hercynian Armorican belt (France). An overview
}

Denis Gapais, Jean-Pierre Brun, Charles Gumiaux, Florence Cagnard, Gilles Ruffet, Christian Le Carlier de Veslud

\section{- To cite this version:}

Denis Gapais, Jean-Pierre Brun, Charles Gumiaux, Florence Cagnard, Gilles Ruffet, et al.. Extensional tectonics in the Hercynian Armorican belt (France). An overview. Bulletin de la Société Géologique de France, 2015, 186 (2-3), pp.117-129. 10.2113/gssgfbull.186.2-3.117 . insu-01140598

\section{HAL Id: insu-01140598 https://hal-insu.archives-ouvertes.fr/insu-01140598}

Submitted on 21 Aug 2015

HAL is a multi-disciplinary open access archive for the deposit and dissemination of scientific research documents, whether they are published or not. The documents may come from teaching and research institutions in France or abroad, or from public or private research centers.
L'archive ouverte pluridisciplinaire HAL, est destinée au dépôt et à la diffusion de documents scientifiques de niveau recherche, publiés ou non, émanant des établissements d'enseignement et de recherche français ou étrangers, des laboratoires publics ou privés. 
Extensional tectonics in the Hercynian Armorican belt (France). An overview

Denis Gapais ${ }^{1}$, Jean-Pierre Brun ${ }^{1}$, Charles Gumiaux², Florence Cagnard ${ }^{3}$, Gilles Ruffet $^{1}$, Christian Le Carlier de Veslud ${ }^{1}$

${ }^{1}$ Géosciences Rennes, UMR CNRS 6118, Université de Rennes 1, 35042 Rennes

cedex, France

${ }^{2}$ ISTO, Université d'Orléans / UMR CNRS 7327, 45071 Orléans cedex 2, France

${ }^{3}$ BRGM, Avenue Claude Guillemin, 45060 Orléans cedex, France

Corresponding author: denis.gapais@univ-rennes1.fr

Key words: Tectonics, Hercynian belt, convergence, extension, strike-slip, Armorican Massif

Mots clés: tectonique, chaîne hercynienne, convergence, extension, décrochement, massif armoricain 


\section{Abstract}

A synthesis of existing geological, structural and geophysical data shows that the south Armorican Hercynian belt was marked by syn-convergence crustal thinning and dextral wrenching that were in part coeval in late Carboniferous times. Our kinematic model is further supported by new structural data and ${ }^{40} \mathrm{Ar} /{ }^{39} \mathrm{Ar}$ ages on synkinematic leucogranites. Extension and strike-slip followed earlier crustal thickening and exhumation of high-pressure metamorphic units in late Devonian-early Carboniferous times. Crustal extension led to the development of core complexes cored by migmatites and crust-derived granite laccoliths. At this time, the South Armorican Shear Zone acted as a transfer zone separating the extending domain of South Brittany from the non-extending domain of Central Brittany submitted to dextral wrenching. The overall structural pattern and attached kinematics are compared with recent numerical models and illustrated by a 3D interpretative model that integrates geological and deep seismic reflection data (ARMOR 2 profile).

\section{Résumé}

Une synthèse des données géologiques, structurales, géophysiques et géochronologiques disponibles dans la chaîne hercynienne armoricaine montre que cette région est marquée au Carbonifère supérieur par la combinaison d'amincissement crustal et de décrochement dextre, dans un contexte général de convergence. Ce modèle cinématique est conforté par de nouvelles données structurales et géochronologiques (âges ${ }^{40} \mathrm{Ar} /{ }^{39} \mathrm{Ar}$ sur des leucogranites synkinematiques). Extension et décrochement font suite à un épisode d'épaississement crustal majeur marqué, en outre, par l'exhumation d'unités 
métamorphiques de haute pression au cours du Dévonien terminal-Carbonifère inférieur. L'extension crustale a conduit au développement de dômes migmatitiques bordés de granites crustaux laccolitiques. A cette époque, le Cisaillement Sud Armoricain jouait le rôle d'une zone de transfert entre le domaine sud-armoricain, domaine épaissi, se rééquilibrant par extension longitudinale parallèle à la chaîne, et le domaine centre armoricain déformé en contexte décrochant. Les structures crustales associées sont illustrées par un modèle interprétatif 3D qui intègre les données de géologie de surface et la sismique réflexion écoute longue (profil ARMOR 2). 


\section{Introduction}

The Armorican Hercynian belt comprises three main domains separated by two main dextral wrench zones, the North and the South Armorican Shear Zones (NASZ and SASZ)(fig. 1): a northern domain essentially made of a Proterozoic basement that belonged to the upper brittle crust during the Hercynian orogeny [Brun et al., 2001 and refs. therein]; a central domain made of sediments ranging from Upper-Proterozoic to Carboniferous in age and affected by moderate deformation under overall greenschist facies metamorphic conditions [Gumiaux et al., 2004a, b, and refs. therein]; and the southern domain of south Brittany corresponding to the most internal zones of the belt [see Ballèvre et al., 2013 for a review].

Following early works arguing for strike-slip across Central Brittany [Gapais and Le Corre, 1980; Percevault and Cobbold, 1982], strain removal throughout this region has shown that it was deformed by overall dextral strike-slip simple shear [Gumiaux et al., 2004a, b]. Shearing was partly synchronous with the emplacement of leucogranite plutons [Berthé et al., 1979; Jégouzo, 1980; Vigneresse and Brun, 1983]. A major outcome of these works is that central Brittany did in overall not thicken during the Hercynian orogeny. This is in strong contrast with southern Brittany that underwent crustal thickening and high-pressure metamorphism [see Ballèvre et al., 2013 for a review].

In the late nineties-early 2000 s, a deep seismic reflection profile has been acquired across the entire internal zone of the belt, from the northern branch of the SASZ down to the town of Les Sables d'Olonne where the belt becomes covered by Mesozoic sediments of the Aquitaine basin (fig. 1) [Bitri et al., 2003, 2010]. In the 
present paper, we reappraise the geological and structural data of the area in the light of geochronological and geophysical information.

\section{Main geological units of southern Brittany}

South of the SASZ, the internal zones of the belt show three main groups of units (figs. 1, 2), from top to bottom.

- Upper units, mainly blueschists (Ile de Groix and Bois de Céné) and metavolcanics (Vendée porphyroids) marked by metamorphic histories of HPLT type that reached peak PT conditions of $1.4-1.8 \mathrm{GPa}, 550^{\circ} \mathrm{C}$ [Bosse et al., 2002] and 0.8 GPa, 350-400 C [Le Hébel, 2002; Le Hébel et al., 2002a, 2007], respectively.

- Intermediate units mainly made of micaschists affected by a Barrovian metamorphism increasing downwards from greenschist to amphibolite facies conditions [Bossière, 1988; Triboulet and Audren, 1988; Goujou, 1992].

- Lowermost units made of high-grade metamorphic rocks corresponding to the lower part of the Barrovian pile and comprising gneisses and migmatites. These crop-out as dome-like windows (e.g. Golfe du Morbihan area, fig. 1; 0.8 GPa, $700-750^{\circ} \mathrm{C}$ [Jones and Brown, 1990]).

Concerning magmatism, a major feature of the region is the widespread occurrence of two-mica leucogranites, mainly concentrated along the SASZ [Jégouzo, 1980; Tartèse et al., 2011, 2012 and refs. therein], and along extensional 
shear zones in southern Brittany [Gapais et al., 1993; Turillot et al., 2009, 2011]. Their origin is attributed to partial melting of pelitic sediments [Bernard-Griffith et al., 1985; Tartèse and Boulvais, 2010].

\section{Structural and geochronological backgrounds}

Concerning the Barrovian units, available geochronological data indicate that they were exhumed during late Carboniferous times, around $310 \mathrm{Ma}$ [Goujou, 1992; Gapais et al., 1993 and refs. therein; Brown and Dallmeyer, 1996; Turillot et al., 2011]. It has been further emphasized that the exhumation of lowermost migmatites, like those from the Golfe du Morbihan, was a rapid event [Gapais et al.,1993; Brown and Dallmeyer,1996] resulting from crustal-scale extension [Gapais et al., 1993; Cagnard et al., 2004; Turillot et al., 2009, 2011].

For the upper HP-LT units, geochronological works (U/Pb, ${ }^{40} \mathrm{Ar} /{ }^{39} \mathrm{Ar}$ and $\mathrm{Rb} / \mathrm{Sr}$ ) have shown that HP metamorphism and exhumation corresponded to early events in the tectonic history, from ca. 370 Ma to 350-345 Ma [Bosse et al., 2002, 2005; Le Hébel, 2002; El Korh et al., 2011]. In Vendée, north of the Sables d'Olonne (fig.1), strongly deformed porphyroids metamorphosed under HP-LT metamorphic conditions (Le Hébel et al.,2002a) are thrust over the low-grade sediments that constitute the top of the Barrovian pile [Iglesias and Brun, 1976] (fig. 3). Some sediments of the footwall of the thrust were attributed to the Tournaisian [Colchen and Poncet, 1987, 1989; Colchen and Rolin, 2001], which would be consistent with youngest $\mathrm{Ar}-\mathrm{Ar}$ and $\mathrm{Rb} / \mathrm{Sr}$ dates obtained from the blueschists and porphyroids that situate their final exhumation around 350-345 Ma [Bosse et al., 2002; Le Hébel, 
2002, Béchennec et al., 2008; Ballèvre et al., 2011]. Except in the vicinity of granitic intrusions, like in the Guérande area (fig. 1), available ${ }^{40} \mathrm{Ar} /{ }^{39} \mathrm{Ar}$ dates on white micas in both blueschists and porphyroids do not reveal any significant thermal event later than ca 345 Ma [Bosse et al., 2002, 2005; Le Hébel, 2002; El Korh et al., 2011]. From this, one can infer that these units were in the upper part of the tectonic pile since early Carboniferous times. Consistently, the latest structures in these units are brittle to semi-brittle systems of normal faults [Philippon et al., 2009; Ballèvre et al., 2013].

\section{Modes of extension}

\subsection{Field data}

Gapais et al. [1993] underlined the importance of extensional tectonics in South Brittany during the Upper Carboniferous. At this time, we argued for a detachmenttype geometry in the Quiberon area (fig. 4). There, migmatite bearing units from the Golfe du Morbihan are exhumed below upper crustal HP units (fig. 4). The overall geometry is that of a core complex, lower migmatitic units being juxtaposed with upper crustal ones along a low angle normal shear zone marked by sheets of synkinematic leucogranites affected by pervasive S-C fabrics indicating top-to-theNW shearing (fig. 4) [Gapais et al., 1993].

However, foliation attitudes and associated shear senses are locally variable [Gapais et al., 1993]. Especially, the eastern part of the Golfe du Morbihan migmatite core shows syntectonic leucogranites marked by pervasive $S-C$ fabrics that are flat- 
lying and indicate top-to-the south-east motions [Gapais et al., 1993] (fig. 4a). This was further argued by more recent studies [Turillot et al., 2009, 2011].

In the area of the Vilaine estuary (figs. 1,5,6), stretching lineations associated with extension are in fact rather variable, showing some tendency to adopt radial attitudes with respect to the variable strike of the interface between micaschists that host granites and underlying migmatite bearing units [Gapais et al., 1993]. This is illustrated by a lineation map (fig. 5a), as well as by a plot of lineation pitch versus foliation strike that underlines rather variable strikes with respect to pitches that are higher than $40^{\circ}$ (fig. $5 \mathrm{~b}$ ).

At very local scale, the area may also show contrasting extensional shear senses. Thus, in the northern part of the Guérande granite and overlying country rocks, NNESSW stretching lineations associated with S-C fabrics are observed at granite roof (fig. 6a); whereas contact metamorphic patches and tilted blocks attest to EW stretch in adjacent country rocks (fig. 6b, c) [see also Ballouard et al., submitted].

At the scale of the whole southern Brittany, stretching lineations associated with the Barrovian type metamorphism trend however dominantly E-W to NW-SE and are associated with top-to-the west sense of shear [Brun and Burg, 1982; Vauchez et al., 1987; Goujou, 1992; Gapais et al., 1993; Cagnard et al., 2004]. Associated detachment zones trend dominantly NS to NW-SE, connected by dextral transfer zones running subparallel to the SASZ (fig. 2).

4.2. Pattern of extension at crustal-scale from deep seismic profiling 
Figure 7a shows the geological map around the Armor 2 seismic profile. The interpreted profile and extracted main reflexions are shown in figure $7 \mathrm{~b}$ and $\mathrm{c}$, respectively. The interpretation of the seismic profile is constrained by field data and completed in its northern part by a cross-section through Central Brittany. Details on geophysical data and data processing are available in Bitri et al. [2003, 2010].

Main features are the followings.

- The Central Armorican domain, the Champtoceaux domain and the South Armorican domain have different seismic signatures [Bitri et al., 2003]. In the upper crust, Central Brittany is marked by an overall poor reflectivity, the Champtoceaux domain shows north dipping reflectors cut by south dipping ones, and the South Brittany domain shows complex structures dominated by overall north dipping reflexions.

- The SASZ is marked by significant loss of reflectivity and cannot be followed down to the Moho. Instead, it is cut by gently southward dipping reflections around 15-20 km depth. At higher structural levels, these structures appear to split in several thrusts that offset strong northward dipping reflections interpreted as associated to eclogitic units of the Champtoceaux area [Bitri et al., 2003; Martelet et al., 2004]. According to geological data, these reflections merge into thrust-wrench zones recognised in the field between the northern and southern branches of the SASZ (e.g. Nort-sur-Erdre fault zone, NEFZ) (fig. 7).

- The southern part of the profile shows a flat-lying band of high reflectivity at about 10-12 km depth [Bitri et al., 2010] (fig. 7b, c). A somewhat comparable but weaker band appears at a higher level, joining the high reflectivity band in 
the southern part of the profile. The high reflectivity band can be followed over a long distance and does not appear disturbed by overlying or underlying reflections (fig. 7c).

- In the upper crust, the high reflectivity band appears to cut other ones that can be correlated at the surface with thrust systems that mark the base of the HPLT units (figs. 2 and 7).

- To the north, the high reflectivity band appears to merge in the St Nazaire migmatitic dome that crops out just west of the profile (fig. 7b). This dome shows an overall geometry comparable to that of the Golfe du Morbihan migmatite dome that was exhumed during regional extension [Gapais et al., 1993] (fig.4).

- To the south of the profile, the high reflectivity zone appears to merge in the Sables d'Olonne migmatite-cored dome (fig. 7). In the field, this area is marked by a Barrovian metamorphic gradient from greenschist facies to the north down to partial melting conditions in the southern part of the town of Les Sables d'Olonne. A detailed structural analysis and the geometry of metamorphic isograds show that the metamorphic pile was thinned by about $80 \%$ in a basically pervasive way [Cagnard et al., 2004]. A comparable thinned metamorphic pile marks the southern top of the St Nazaire dome in the region of St-Brévin-les-Pins, south of the Loire estuary (fig. 7).

- The crust below the high reflectivity zone is marked by three dome shaped structures (fig. 7 b, c). The northern one corresponds to the St Nazaire dome. The two other may be tentatively correlated to the La Roche-sur-Yon and 
Aubigny high grade domes that crop out to the east of the profile (fig. 7) [Bitri et al., 2010].

A 3D structural model of the Vendée area combining surface and seismic data was built using the gOcad 3D modeler [Mallet, 2002] (fig. 8). For this purpose, outcrop, literature and seismic data [Godard, 2001; Bitri et al., 2010] were collected and integrated in 3D. Then, triangulated surfaces representing the geological structures were built by interpolation from the data, in order to obtain a geologically and geometrically consistent 3D model [Caumon et al., 2009]. The work was basically focused on one issue: the geometry of the main extensional deformation zone highlighted in this area. The 3D model underlines that the map trace of the normal shear zone that bounds the Aubigny and La Roche-sur-Yon dome area to the east of the seismic profile (fig. 7a) can be correlated at depth with the flat lying zone of high reflectivity observed on the seismic profile (yellow-greenish surface, fig. $8 b, c)$. To the $\mathrm{N}$, this structure merges in a SW-verging thrust-wrench zone marked by exhumed eclogites in its hanging wall (fig. 7a) [Godard, 2001]. The model is locally under-constrained, but the proposed geometry may be considered as a reasonable semi-quantitative 3D model.

\section{New geochronological constraints}

In order to further constrain time relationships between extension and activity of the SASZ, some ${ }^{40} \mathrm{Ar} /{ }^{39} \mathrm{Ar}$ dates where recently performed within syn-kinematic 
leucogranites. We show here new results from two granitic intrusions: a synkinematic S-C leucogranite emplaced along the SASZ and granite mylonites and ultramylonites sampled along the zone (fig. 9a), and the Quiberon granite emplaced during extension in the South Armorican domain (fig. 9b).

Main results are as follows.

- White micas from mylonitic and ultramylonitic leucogranites sampled on the SASZ (Lostihuel quarry, fig. 1) yielded ${ }^{40} \mathrm{Ar} /{ }^{39} \mathrm{Ar}$ ages of $308 \pm 0.4$ and $299.5 \pm$ 0.4 Ma (fig. 9a). Consistently, S-C pegmatites from the La Roche-Bernard leucogranite, also emplaced along the SASZ (fig. 1), provided $a^{40} \mathrm{Ar} /{ }^{39} \mathrm{Ar}$ age of $303.5 \pm 0.7 \mathrm{Ma}$ (fig. 9a).

- $\quad$ The Quiberon syn-extension leucogranite provided white mica ${ }^{40} \mathrm{Ar} /{ }^{39} \mathrm{Ar}$ ages of $301 \pm 0.7 \mathrm{Ma}$ and $300 \pm 0.4 \mathrm{Ma}$ for foliated samples and pegmatites, respectively (fig. 9b). Biotites from the same outcrop provided less precise dates, but consistent in age (fig. 9b).

These new ages are consistent with those recently obtained on other synkinematic granitic intrusions along the SASZ [Tartèse et al., 2011, 2012].

\section{Discussion}

\subsection{Core complexes of Southern Brittany}

Structures as observed in the Quiberon area, where a normal sense shear zone juxtaposes lower crustal, partially molten rocks, with upper crustal units affected by brittle deformation during late Carboniferous extension, clearly points to a 
metamorphic core complex geometry [Gapais et al. 1993]. However, the regional scale pattern presents some discrepancies with classical textbook models of core complexes. First, as displayed by the Southern Brittany map (figs. 1 and 2), the overall contours of exhumed migmatites and granites that constitute most core complexes rocks are made of rather short segments trending at high angle to the mean direction of stretching, corresponding to pure detachments. These appear connected to deformation zones almost parallel to the trend of the SASZ that likely correspond to lateral transfer zones internal to the extending domain. Along these zones, deformation could have occurred through different combinations of extensional and strike-slip shear that might explain the observed variations in stretching directions and senses of shear (figs. 5, 6). Second, syn-extension sedimentary basins in detachment hanging-walls and transition from ductile to brittle deformations along detachments, as described in other core complexes [see Brun and Van Den Driessche, 1994, and refs. therein] are not observed in Southern Brittany. This may be due to the poor quality of outcropping conditions away from the coast-line and to deep erosion since the end of the Hercynian cycle.

\subsection{Seismic imaging of lower crustal flow}

Numerical modelling of core complex development (fig. 10a) [Tirel et al. 2008] provides a simple explanation to several features observed on the seismic profile and in particular the long flat lying zone of high reflectivity at 10-12 km depth (fig. 7). A core complex corresponds to the ductile crust that is exhumed between two separating upper crust blocks leading to a metamorphic dome bounded by upper 
crustal units (fig. 10a). In most situations, the exhumation is asymmetrical and controlled by an upward convex detachment zone located on one limb of the metamorphic dome. During exhumation, the exhuming ductile crust undergoes progressive cooling and therefore crosses the brittle-ductile transition that, in the model shown in figure $10 \mathrm{a}$, corresponds to the $400^{\circ} \mathrm{C}$ isotherm. Models show that a flat-lying zone of high shear strain localizes below the $600^{\circ} \mathrm{C}$ isotherm (fig. 10a). It results from the horizontal flow of hot lower crust towards the zone of actual exhumation that is located below the detachment zone. In other terms, the location of this zone of high shear strain is controlled by temperature (close to $600^{\circ} \mathrm{C}$ in the model) in the ductile crust. This high strain zone continuously lengthens during increasing extension and core complex widening. To apply this prominent model feature to the seismic line (fig. 7), one must keep in mind that the seismic profile runs almost perpendicular to the stretching direction. However, due to the non-cylindrical shape of migmatite domes, it can be observed that the high reflectivity zone merges into the St Nazaire migmatite dome to the north and to the Sables d'Olonne migmatites to the south in a way directly comparable to the high strain zone of the model. . Comparison between numerical models (Fig 10a) and seismics (Fig. 7) strongly suggests that the zone of high reflectivity represents the upper boundary of lower crustal flow during late Carboniferous extension.

\subsection{The Vendée section: a complete section of the extending crust from upper crust to lower crustal flow.}


The coast-line section of Vendée, from the basal contact of the Porphyroid Nappe to the north (Brétignolles-sur-Mer) to the Sables d'Olonne to the south (figs. 3, 7) [Cagnard et al., 2004] provides a complete section of the extending crust from the upper brittle crust to the high strained zone representing the top part of lower crustal flow as illustrated by the seismic line, in agreement with model predictions.

To the north, the Paleozoic sediments display deformations related to the emplacement of the Porphyroid Nappe but almost no deformation related to Late Carboniferous extension (fig. 3). Together with the Porphyroid Nappe, this upper part of the Paleozoic sedimentary pile represents the upper crust during extension. Moving southward as metamorphism (and therefore temperature) increases, the Paleozoic sediments are affected by pervasive ductile extension and crustal thinning [Cagnard et al., 2004] whose intensity increases southward but with a constant $\mathrm{N} 110^{\circ}$ orientation of stretching and a constant top to WNW sense of shear. Finally, close to the Sables d'Olonne, the partially molten sediments and underlying orthogneisses that are strongly stretched in an ESE-WSW direction and a constant top to WNW sense of shear, corresponds to the top of the lower crustal flow where rocks are strongly weakened by partial melting.

\subsection{Variations in stretching directions and shear sense}

Concerning motions associated with extension, regional scale shear sense indicators impose overall top-to-the west motions [Goujou, 1992, Gapais et al., 1993]. However, structural data show that extension directions and associated sense may vary at local scale (figs. 4, 5, 6) [Gapais et al., 1993; Turillot et al., 2009]. These 
variations may have resulted from either the complexity of core complex contours (see section 6.1) and/or lateral variations in ductile crust rheology. Along detachments that initially trend strongly oblique to the regional direction of extension, stretching directions and senses of shear are rather stable and stretching is close to the regional direction of extension. In contrast, along lateral transfer zones, which trend slightly oblique to the regional direction of extension, ductile material can be exhumed from below the adjacent non-extended crust. Such process can be enhanced by the existence of strong rheological contrasts within the ductile crust, like for example related to large volumes of buoyant granitic magmas. In such circumstances, local stretching directions can trend strongly oblique to the lateral transfer zone and therefore also to the regional direction of extension, as observed for example in the Guérande granite pluton (fig. 6). More generally, variations in shear directions at local and regional scales (figs. 5 and 6) may further suggest overall horizontal flattening (oblate) strains associated with extension.

\subsection{Synchronism between extension and wrenching along the SASZ}

The southern branch of the SASZ marks the northern boundary of Southern Brittany that was submitted to crustal extension during the late Carboniferous. This underlines that terrains located north of the southern branch of the SASZ were exhumed before late Carboniferous times and were not affected by late Carboniferous extension.

Geochronological data (fig. 9) show that extension in Southern Brittany was at least partly coeval with dextral motions along the SASZ. This result is consistent with 
the analysis of Gumiaux et al. [2004] concluding that the SASZ had acted as a transfer zone between a southern thickened hot domain submitted to crustal thinning and a northern more stable one, only affected by dextral strike-slip simple shear.

Within the Golfe du Morbihan migmatitic dome, the NS to NNE-SSW attitude of feeding granite dykes of overlying granite sheets (fig. 4a) [Turillot et al., 2009, 2011] emphasizes that dextral wrenching along the ESE trending SASZ and overall E-W extension south of it were in part coeval.

6.6. Relationships between wrenching along the $S A S Z$ and regional convergence

Seismic imaging [Bitri et al., 2003] emphasized that the southern branch of the SASZ is cut in the lower crust by south dipping thrust-wrench faults that separate different units recognised on the geological map between the southern and the northern branches of the SASZ (e.g. NEFZ, fig. 7) [Chantraine et al., 1996]. Surface geology actually shows that these transpressive fault zones merge into the SASZ. Following field evidence and 3-D geophysical modelling, Gumiaux et al. [2004] and Martelet et al. [2004] concluded that dextral motions along the SASZ were at least in part coeval with thrusting events north of its southern branch. From these features, we infer that wrenching along the SASZ and thrusting were in part coeval.

\subsection{Relationships between extension and convergence}

Geophysical and field data, in the Eastern part of the studied domain (Champtoceaux and Loire estuary), do emphasize that crustal-scale thrusting did 
occur during wrenching along the SASZ. Other lines of evidence converge toward this inference. Indeed, pioneer structural works in the Sables d'Olonne area have argued for both EW regional stretching and NS directed thrusting [Iglesias and Brun, 1976; Brun and Burg, 1982; Cannat and Bouchez, 1986]. Brun and Burg [1982] proposed a combination of thrust and wrench tectonics to account for observed strain patterns. On the other hand, Cannat and Bouchez [1986] argued for two different deformation events. Cagnard et al. [2004] showed that the EW stretching in the area was actually due to crustal thinning and overall E-W directed extension. The southernmost part of the metamorphic pile in the Sables d'Olonne area is nevertheless marked by top-to-the-south thrusting kinematic indicators that share same high grade metamorphic conditions [Brun and Burg, 1982; Cannat and Bouchez, 1986], which strongly suggest that the area shows crustal thinning of a weak and hot crust above an active thrust system at the front of the orogen. A comparable deformation pattern was for example described in the western Himalayas, where hot and weak rocks of the higher Himalaya Crystalline underwent along-strike horizontal spreading during their exhumation that was coeval with active thrusting along the underlying frontal Himalayan thrust system [Gapais et al. 1992]. Similarly, in the lle d'Yeu orthogneiss, west from the Sables d'Olonne, the main deformation features attest to southward directed thrusting [Sassier et al., 2005]. There, a recent geochronological study of syn-thrusting shear zones yielded a U-Pb date on monazites of $306.0 \pm 4,7 \mathrm{Ma}$ [Pitra and Ruffet, personal communication].

Field evidence discussed above corresponds to the eastern part of the studied area where it has been shown that wrenching combined with thrusting at the intersection between the probable suture zone and the SASZ (figs. 3 and 7; Martelet 
et al., 2004; Gumiaux et al., 2004b). This may have contributed to the local offset of the suture zone by the SASZ, isolating the Champtoceaux metamorphic units from the rest of the Southern Brittany Domain, to the North of the SASZ. Nevertheless, it cannot be excluded that combination of NS shortening and overall EW stretching could be related to local pre-existing geometrical complexities and not reflect the overall kinematics at the scale of the whole orogen.

\subsection{Tectonic significance of the South Armorican shear zone}

During several decades and up to recently, the Hercynian orogeny of Western Europe has been considered to be directly comparable to the India-Asia collision and the Ibero-Armorican arcuate belt has been directly compared to the western syntaxis of the Himalayas (see fig. 9 in Matte, 1991). In this frame, the South Armorican Shear Zone would be an equivalent of the Karakorum Fault (Lacassin et al., 2004) that offsets the Yalu-Tsangpo Suture Zone in the Eastern branch of the syntaxis. However, immediately to the North of the SASZ, the crust of Central Brittany, has

never been significantly thickened (fig. 2) and therefore cannot be compared to Tibet, to the North of the Karakorum Fault, where crustal thicknesses reach $70-80 \mathrm{Km}$ (Braitenberg et al., 2000). This major difference renders a continental collision model of India-Asia type difficult to argue for the Hercynian Belt of Brittany.

Conversely, the sequence of tectonic and metamorphic events observed in Southern Brittany (exhumation of HP metamorphism followed by widespread extension with migmatitic core complex development) is strongly reminiscent of those observed in back-arc domains of the Mediterranean sea where extension driven by 
slab rollback led to the exhumation of HP metamorphic rocks later followed by exhumation of migmatites in core complexes (Brun and Faccenna, 2008). At large scale, slab rollback is also responsible for the formation of arcuate belts in the Mediterranean: Aegean, Apennine-Calabria and Rif-Gibraltar-Betics (Faccenna et al., 2004). In these three examples, the arcuate belt amplification during ongoing slab rollback evolved asymmetrically with one arc branch becoming a major strike-slip belt. The SASZ that is at least synchronous with regional-scale extension in the South Armorican Domain could likely represent the transfer zone that accommodated the formation of the Ibero-Armorican arcuate Belt. From this point of view, it is remarkable that in the central part of Southern Brittany principal directions of stretching in the SASZ and in the Golfe du Morbihan core complex are almost parallel (see section 6.5 \& figs. 5 and 10 ).

In summary, whereas the Hercynian tectonic history of Central and Southern Brittany cannot be explained by an India-Asia-type collisional model, the sequence of metamorphic events and the overall kinematics suggest that the Hercynian tectonic evolution of Brittany, with in particular the relation between the SASZ and Southern Brittany extension, could reflect back-arc type extension driven by slab rollback, as observed in the Mediterranean. Such a frame might provide a fruitful working hypothesis for future studies at the scale of the whole Ibero-Armorican arcuate Belt.

\section{Conclusions}


From a synthesis of available structural, geochronological, and geophysical data, our main conclusions concerning tectonics of the internal zones of the Armorican Hercynian belt are the followings.

- The late Carboniferous extension that affects the South Armorican Belt appears basically expressed by pervasive crustal thinning, overall vertical flattening strains, and detachments.

- The upper crust preserved in hanging walls of extensional deformation zones records HP-LT metamorphic conditions associated with early tectonic processes of burial and exhumation of late Devonian-early Carboniferous age. During subsequent late Carboniferous extension, these units are affected by brittle to semi-brittle systems of normal faults.

- Extension in the South Armorican belt is limited to the north by the SASZ that acted as a transfer zone.

- Extension was likely a syn-convergence process, with coeval crustal shortening and dextral wrenching along the SASZ.

\section{Acknowledgements}

This paper benefited from several field studies made by M.Sc. students in the area since the nineties. It has strongly benefited from the Geophysical Program "Geofrance 3D" and the associated "ARMOR 2" program driven by the BRGM and INSU that included a deep seismic reflection section throughout the internal zones of the Hercynian belt of Brittany and Vendée. Reviews by Y. Rolland, K. Schulmann, P. Rossi and the Editor revealed quite constructive. 


\section{References}

Ballevre M., Bosse V., Dabard M.P., Ducassou C., Fourcade S., Paquette J.L., PeUCAT J.J. \& PItRA P. (2013). - Histoire géologique du Massif armoricain: actualité de la recherche. - Bull. Soc. Géol. Minéral. Bretagne, 10-11, 5-96.

Ballèvre M., Fourcade S., Capdevila R., Peucat J.J., Cocherie A. \& Fanning C.M., (2011). - Geochronology and geochemistry of Ordovician felsic volcanism in the Southern Armorican Massif (Variscan belt, France): Implications for the breakup of Gondwana. - Gondwana Research, doi:

10.1016/j.gr.2011.07.030

Ballouard C., Boulvais P., Gapais D., Poujol M., Yamato P., Tartèse R. \& Cuney M. (submitted). - Tectonic record, magmatic history and element mobility in the Hercynian Guérande leucogranite, Armorican Massif, France. - Lithos, submitted.

Bechennec F., Chèvremont P., Stussi J.M. \& Thiéblemont D. (2008).- Geological Map of France at 1:50,000 scale, Le Poiré-sur-Vie Sheet (561), BRGM Orléans, 180p. - Explanatory notes: Béchennec F., Chèvremont P., Stussi J.M., Thiéblemont D., Cocherie A. and Roy C. (in French).

Bernard-Griffiths J., Peucat J.J., Sheppard S. \& Vidal P. (1985). - Petrogenesis of Hercynian leucogranites from the South Armorican Massif: contribution of $\mathrm{REE}$ and istopic ( $\mathrm{Sr}, \mathrm{Rb}, \mathrm{Pb}$ and $\mathrm{O}$ ) geochemical data to the study of source rock characteristics and ages. - Earth Planet. Sci. Lett., 74, 235-250.

Berthe D., Chroukroune P., \& Jegouzo P. (1979). - Orthogneiss, mylonite amnd non-coaxial deformation $f$ granite: the example of the South Armorican Shear Zone. - J. Struct. Geol., 1, 31-42. 
Bitri A., Ballevre M., Brun J.P., Chantraine J., Gapais D., Guennoc P., Gumiaux C. \& TRUFFERT C. (2003). - Imagerie sismique de la zone de collision hercynienne dans le sud-est du Massif armoricain (projet Armor 2/programme GéoFrance 3D). - C. R. Geoscience, 335, 969-979.

Bitri A., Brun J.P., Gapais D., Cagnard F., Gumiaux C., Chantraine J., Martelet G. \& TRUFFERT C. (2010). - Deep reflection seismic imaging of the internal zone of the South Armorican Hercynian belt (western France) (Armor2/GéoFrance 3D Program). - C. R. Geoscience, 342, 448-452.

Bosse V., BallèVRe M. \& Vidal O. (2002). - Ductile thrusting recorded by the garnet isograd from blueschists-facies metapelites of the lle de Groix, Armorican Massif, France). - J. Petrol., 43, 485-510.

Bosse V., Féraud G., Ballèvre M., Peucat J.J. \& Corsini M. (2005). - Rb-Sr and ${ }^{40} \mathrm{Ar} /{ }^{39} \mathrm{Ar}$ ages in the blueschists from the lle-de-Groix (Armorican Massif, France): implications for closure temperatures. - Chemical Geology, 221, 21-45.

BossieRE G. (1988). - Evolutions chimico-minéralogiques du grenat et de la muscovite au voisinage de l'isograde biotite-staurotide dans un métamorphisme prograde de type Barrovien: un exemple en Vendée littorale (Massif Armoricain). - C. R. Acad. Sci., Paris, Série II, 306, 135-140.

Braitenberg C., Zadro M., Fang J., Wang Y. \& Hsu H.T. (2000). - The gravity and isostatic Moho undulations in Qinghai-Tibet plateau. - J. Geodyn., 30, 489505. 
BRown M. \& DALLMEYER R.D. (1996). - Rapid Variscan exhumation and the role of magma in core complex formation: southern Brittany metamorphic belt, France. - J. Met. Geol., 14, 361-379.

BRUN J.P. \& BURG J.P. (1982). - Combined thrusting and wrenching in the lberoArmorican arc: a corner effect during continental collision. - Earth Planet. Sci. Lett., 61, 319-332.

BRUN J.P.\& FACCENNA C. (2008). - Exhumation of high-pressure rocks driven by slab rollback. - Earth Planet. Sci. Lett., 272, 1-7 .doi:10.1016/j.epsl.2008.02.038

BRUN J.P. \& VAN DEN DRIESSCHE J. (1994).-Extensional gneiss domes and detachment fault systems: structure and kinematics. - Bull Soc. Géol. Fr., $165,519-530$.

Brun J.P., Guennoc P., Truffert C., Vairon J. \& the Armor Working Group (2001). - Cadomian tectonics in northern Brittany: the tribute of 3D modelling at crustal scale. - Tectonophysics, 331, 229-246.

Cagnard F., Gapais D., Brun J.P., Gumiaux C.\& Van Den Driessche J. (2004). - Late pervasive crustal-scale extension in the south Armorican Hercynian belt. - J. Struct. Geol., 26, 435-449.

CANNAT M. \& BoucheZ J.L. (1986). - Linéations N-S et E-W en Vendée littorale, (Massif armoricain). Episodes tangentiels successifs éo-hercyniens en France occidentale. - Bull. Soc. Géol. Fr., 7, 299-310.

Chantraine J., Autran A. \& Cavelier C. (1996). - Carte géologique de la France à 1/1 000000 (Geological Map of France). - BRGM, Service Géologique de France, Orléans. 
Caumon G., Collon-Droualllet P., de Veslud C.L.C., Viseur S., Sausse J. (2009). Surface-based 3D modeling of geological structures. - Mathematical Geosciences, 41, 927-945.

Colchen M. \& Poncet D. (1987). - Sur l'âge post-Tournaisien de la tectonique hercynienne synschisteuse à Brétignolles-sur-Mer, Vendée littoral, massif armoricain. - C. R. Acad. Sci. Paris, Série II, 305, 1255-1258.

Colchen M. \& Poncet D. (1989). - Présence, dans la série paléozoïque de Brétignolles-sur-Mer (Vendée, sud du Massif armoricain), d’une formation à blocs et olistholithes d'âge dinantien, conséquences géodynamiques. - $C$. R. Acad. Sci. Paris, Série II, 309, 1503-1507.

Colchen M. \& Rolin P. (2001). - La chaîne hercynienne en Vendée. - Géologie de la France, 1-2, 53-86.

El Korh A., Schmidt S.T., Ballèvre M., Ulianov A. \& Bruguier O. (2011). Discovery of an albite gneiss from the lle de Groix (Armorican Massif, France): geochemistry and LA-ICPMS U-Pb geochronology of its Ordovician protolith. - Int. J. Earth Sci., doi: 10.1007/s00531-011-0732-5.

Faccenna C., Piromallo C., Crespo-Blanc A., Jolivet L. \& Rossetti F. (2004). Lateral slab deformation and the origin of the westernMediterranean arcs. Tectonics, 23, TC1012, doi:10.1029/2002TC001488.

GAPAIS D. \& LE CORRE C. (1980). - Is the Hercynian belt of Brittany a major shear zone? - Nature, 288, 574-576.

Gapais D., PÊCher A., Gilbert A. \& BallèVRe M. (1992). - Synconvergence spreading of the Higher Himalaya Crystalline in Ladakh. - Tectonics, 11, 1045-1056. 
Gapais D., Lagarde J.L.. Le Corre C., Audren C., Jegouzo P., Casas Saintz A. \& VAN Den Driessche J. (1993). - La zone de cisaillement de Quiberon: témoin d'extension de la chaîne varisque en Bretagne méridionale au Carbonifère. - C. R. Acad. Sci. Paris, 316, 1123-1129.

GodARD G. (2001). - Les Essarts eclogite-bearing complex (Vendée). - Geol. France, 1-2, 19-51.

GouJou J.C. (1992). - Analyse pétro-structurale dans un avant-pays métamorphique: influence du plutonisme tardi-orogénique varisque sur l'encaissant épi à mésozonal de Vendée. - Document du BRGM, 216.

Gumiaux C., BRUN J.P. \& GaPAIS D. (2004a). - Strain removal within the Hercynian Shear Belt of Central Brittany (western France): methodology and tectonic implications. In: G.I. Alsop, R.E. Holdsworth, K.J.W. McCaffrey and M. Hand, Eds., Flow processes in faults and shear zones. - Geol. Soc. London Spec. Pub., 224, 287-305.

Gumiaux C., Gapais D., Brun J.P., Chantraine J. \& Ruffet G. (2004b). - Tectonic history of the Hercynian Armorican Shear belt (Brittany, France). Geodinamica Acta, 17, 289-307.

IGLESIAS M. \& BRUN J.P. (1976). Signification des variations et anomalies de la déformation dans un segment de la chaîne hercynienne (les séries cristallographiques de la Vendée littorale, Massif armoricain). - Bull. Soc. Géol. Fr., 18, 1443-1452.

JÉGouzo P. (1980). - The South Armorican shear zone. - J. Struct. Geol., 2, 39-47. 
JONES K.A. \& BROWN M. (1990). - High temperature "clockwise" P-T paths and melting in the development of regional migmatites: an example from Southern Brittany, France. - J. Metam. Geol., 14, 361-379.

Lacassin R., Valli F., Arnaud N., Leloup P.H., Paquette J.L., Haibing L., Tapponnier P., Chevalier M.L., Guillot S., Maheo G. \& ZhiQin X. (2004). Large-scale geometry, offset and kinematic evolution of the Karakorum fault, Tibet. - Earth Planet. Sci. Lett., 219, 255-269.

LE Hebel F. (2002). - Déformation continentale et histoire des fluides au cours d'un cycle subduction, exhumation, extension. Exemple des porphyroïdes sudarmoricains. - Unpublished PhD. Thesis, Université de Rennes1, France.

Le Hebel F., Vidal O., Kienast J.R. \& Gapais D. (2002a). - Les "porphyroïdes" de Bretagne méridionale: une unité de HP-BT dans la chaîne hercynienne. - $C$. R. Geoscience, 334, 205-211.

Le Hébel F., Gapais D., Fourcade S. \& Capdevila R. (2002b). - Fluid-assisted large strains in a crustal-scale décollement (Hercynian belt of south Brittany, France). In: S. De Meer, M.S. Drury, J.H.P. De Bresser and G.M. Pennock, Eds., Deformation Mechanisms, Rheology and Tectonics: current status and future perspectives. - Geol. Soc. London Spec. Pub., 200, 85-101.

Le Hébel F.,Fourcade S., Boiron M.C., Cathelineau M., Capdevila R. \& Gapais D. (2007). - Fluid history during deep burial and exhumation of oil-bearing volcanics, Hercynian belt of southern Brittany, France. - Am. J. Sci., 307, 1096-1125.

MALLET J.L. (2002).- Geomodeling. Applied Geostatistics. Oxford University Press, New York, 624p. 
Martelet G., Calcagno P., Gumiaux C., Truffert C., Bitri A., Gapais D. \& Brun J.P. (2004). - Integrated 3D geophysical and geological modelling of the Hercynian Suture Zone in the Champtoceaux area (south Brittany, France). - Tectonophysics, 382, 117-128.

Matte P. (1991). - Accretionary history and crustal evolution of the Variscan belt in Western Europe. - Tectonophysics, 196, 309-337.

Percevault M.N. \& Cobbold P.R. (1982). - Mathematical removal of regional ductile strains in Central Brittany: evidence for wrench tectonics. - Tectonophysics, 82, 317-328.

Philippon M., Brun J.P. \& Gueydan F. (2009). - Kinematic records of subduction and exhumation in the lle de Groix bluesschists (Hercynian belt, western France). - J. Struct. Geol., 31, 1308-1321.

Sassier C., Boulvais P., Gapais D., Capdevila R. \& Diot H. (2005). - From granitoid to kyanite-bearing micaschist during fluid-assisted shearing (Ile d'Yeu, France). - Int J Earth Sci. doi:10.1007/s00531-005-0011-4.

TARTÈSE R. \& BoulvaIs P. (2010). - Differentiation of peraluminous granites "en route" to the surface. - Lithos, 114, 353-368.

Tartèse R., Poujol M., Ruffet G., Boulvais Yamato P. \& Košler J. (2011). - New $\mathrm{U}-\mathrm{Pb}$ zircon and ${ }^{40} \mathrm{Ar} /{ }^{39} \mathrm{Ar}$ constraints on the emplacement of the Lizio syntectonic granite (Armorican Massif, France). - C. R. Geoscience, 343, 443453.

Tartèse R., Boulvais P., Poujol M., Chevalier T., Paquette J.L., Ireland T.R.\& Deloule E. (2012). - Mylonites of the South Armorican Shear Zone: insights 
to crustal-scale fluid flow and water-rock interaction processes. - $J$. Geodyn., 56-57, 86-107.

TiRel C., BRUN J.P. \& Burov G. (2008). - Dynamics and structural developments of metamorphic core complexes. - J. Geophys. Res., 113, BO4403, doi: 10.1029/2005JB003694.

TRIBOULET C. \& AUDREN C. (1988). - Controls on P-T-t deformation path from amphibole zonations during progressive metamorphism of basic rocks (estuary of the river Vilaine, South Brittany, France). - J. Metam. Geol., 6, 117-133.

Turillot P., Augier R. \& Faure M. (2009). - The top-to-the southeast Sarzeau shear zone and its place in the late-orogenic extensional tectonics of southern Armorica. - Bull. Soc. Géol. Fr., 180, 247-261.

Turillot P., Augier R., Monié P.\& Faure M. (2011). - Late orogenic exhumation of the Variscan high-grade units (South Armorican Domain, western France), combined structural and ${ }^{40} \mathrm{Ar} /{ }^{39} \mathrm{Ar}$ constraints. - Tectonics, 30, TC 5007, doi:10.1029/2010TC002788.

VAuchez A., Maillet D. \& Sougy J.(1987). - Strain and deformation mechanisms in the Variscan nappes of Vendée, South Brittany, France. - J. Struct. Geol., 9, $31-40$.

VIGNERESSE J.L. \& BRUN J.P. (1983). - Les leucogranites armoricains marqueurs de la deformation régionale : aspect de la gravimétrie. - Bull. Soc. Géol. Fr., 3 , $57-366$.

\section{Figure captions}


Fig. 1. - General geological features of the Armorican Hercynian belt. (a) Main structural domains; (b) general geology illustrating the important crustal-derived magmatism of Carboniferous age. The line in (b) marks the trace of the Armor 2 deep seismic reflection profile.

Fig. 2. - Metamorphic map of the Armorican massif outlining the main groups of tectonic units during the Hercynian orogeny. Lines A-A' and B-B'-B" refer to crosssections of figs 3 and 4 , respectively.

Fig. 3. - Illustration of HP-LT porphyroid units thrust over low-grade units of the top of the Sables d'Olonne Barrovian metamorphic pile (Brétignolles-sur-Mer area). (a) Cross-section of the area (located in Fig. 2). (b) Field view of Vendée porphyroids (left) thrust on lower grade Paleozoic sediments (right). (c, d) Fabrics within the Vendée porphyroids marked by extreme E-W stretching under HP-LT metamorphic conditions [Le Hébel et al., 2002a, b]. (e) Aspect of footwall sedimentary rocks showing remnants of superposed folding episodes.

Fig. 4. - Structural field data associated with the Quiberon extensional shear zone. (a) Cross-section of the area (located in Fig. 2). (b) Normal brittle faults in the hanging-wall of the shear zone (Groix blueschists) (width of photograph about $1 \mathrm{~m}$ ). (c) S-C Quiberon granite emplaced in the shear zone (width of photograph about 50 $\mathrm{cm})$. S-C fabrics and associated offsets of pegmatite veins show top-to-the-NW 
shearing. (d) Aspect of migmatites that crop out in the footwall of the shear zone (width of photograph about $50 \mathrm{~cm}$ ).

Fig. 5. - Structural features of the area of the Vilaine estuary (Fig. 1) (modified after [Gapais et al., 1993, Turillot et al., 2009, 2011]). (a) Map showing kinematics associated with extension (arrows). Line B-B'-B" refers to cross section fig. 4a. GM, Golfe du Morbihan migmatites; Q, Quiberon granite; Gu, Guérande granite; S, Sarzeau shear zone; G, lle de Groix blueschists. (b) Plot of foliation strike versus lineation pitch. See text for further explanations.

Fig. 6. - Aspects of local variations of extension directions in the area of the Guérande granite (see figs. 1 and 5 for location). (a) NNE-SSW striking stretching lineation associated with S-C fabrics along the northern roof of the Guérande granite (width of photograph about $20 \mathrm{~cm}$ ). (b) Hornfels metapelite showing contact metamorphic patches stretched along an E-W direction. (c) Extensional tilted blocks attesting to E-W extension in the overlying country-rocks of the Guérande granite (height of cliff about $5 \mathrm{~m}$ ).

Fig. 7. - Summary of seismic information from the Armor 2 Géofrance 3-D program.

(a) Simplified geological map and location of the southern part of the seismic profile.

(b) Interpreted seismic profile attached to a northern cross-section through Central

Brittany. (c) Section showing main seismic reflexions along the Armor 2 south profile (South Armorican domain on (b)). 
Fig. 8. - 3-D modelling of the Vendée area (made using gOcad 3D modeler, [Mallet, 2002]). (a) Available outcrop data. (b) 3D model using (a) and seismic data (fig. 7b), and focused on the geometry of the detachment (yellow-greenish surface). (c) Bloc diagram synthesizing the 3D geometry of the area and the different lithologies. See text for further explanations.

Fig. 9. - New ${ }^{40} \mathrm{Ar} /{ }^{39} \mathrm{Ar}$ data from syn-tectonic leucogranites granites associated with the SASZ and extension in the southern Armorican domain. (a) S-C granite (La Roche-Bernard granite, location fig. 1) and ultramylonites from the SASZ (Lostihuel quarry, location fig. 1). (b) Granite from the Quiberon detachment, including S-C granite and associated late pegmatite dykes. Data underline that both extension and dextral wrenching were in part coeval.

Fig. 10. - (a) Sketch of a numerical model of core complex (after [Tirel et al., 2008].See text for further explanations. (b) Relationships between core complexes, dextral wrenching shear along the SASZ and remnants of pre-extensional thrusts (e.g. fig. 3). 
b)

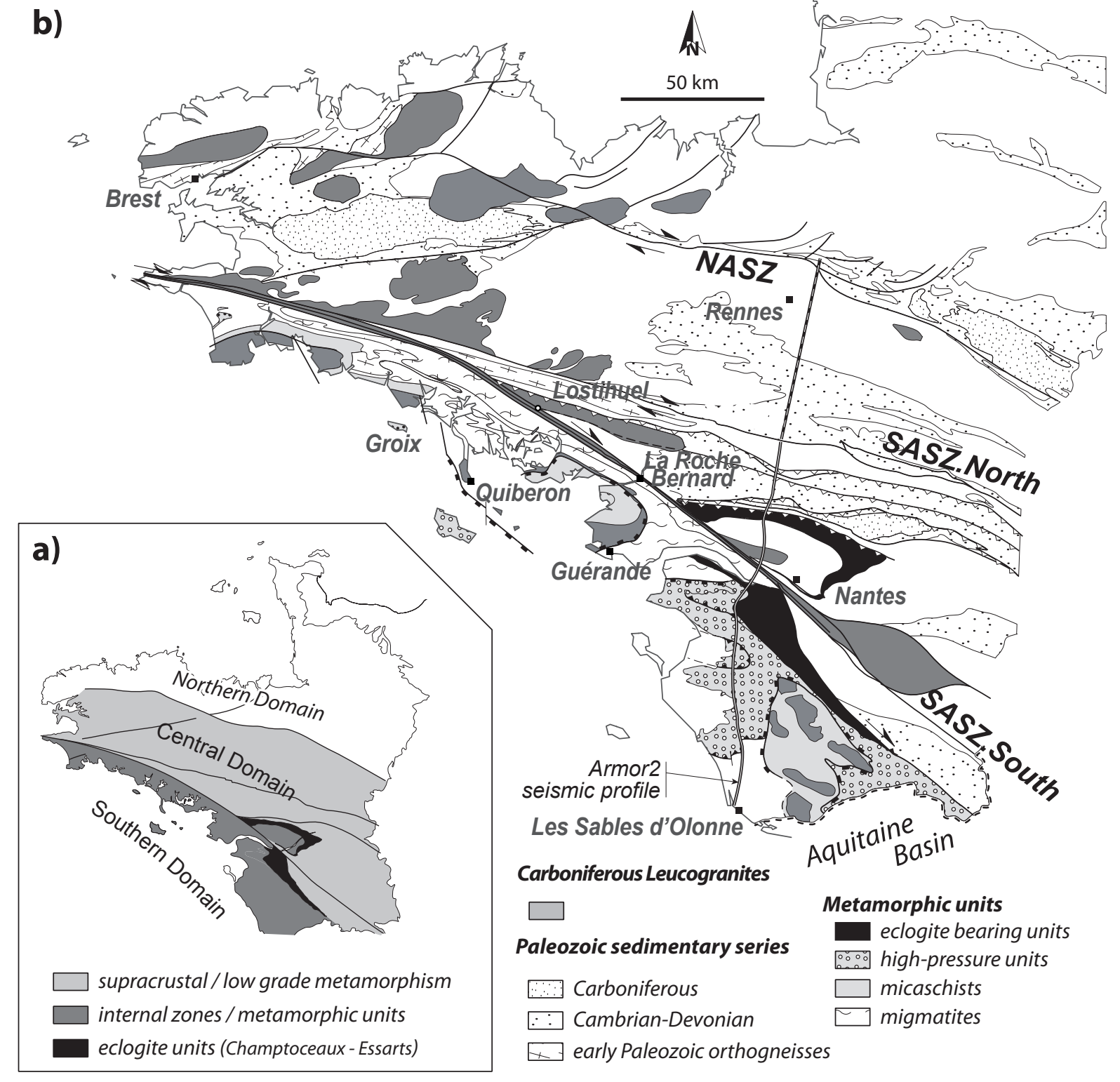

Gapais et al. - Figure 1 


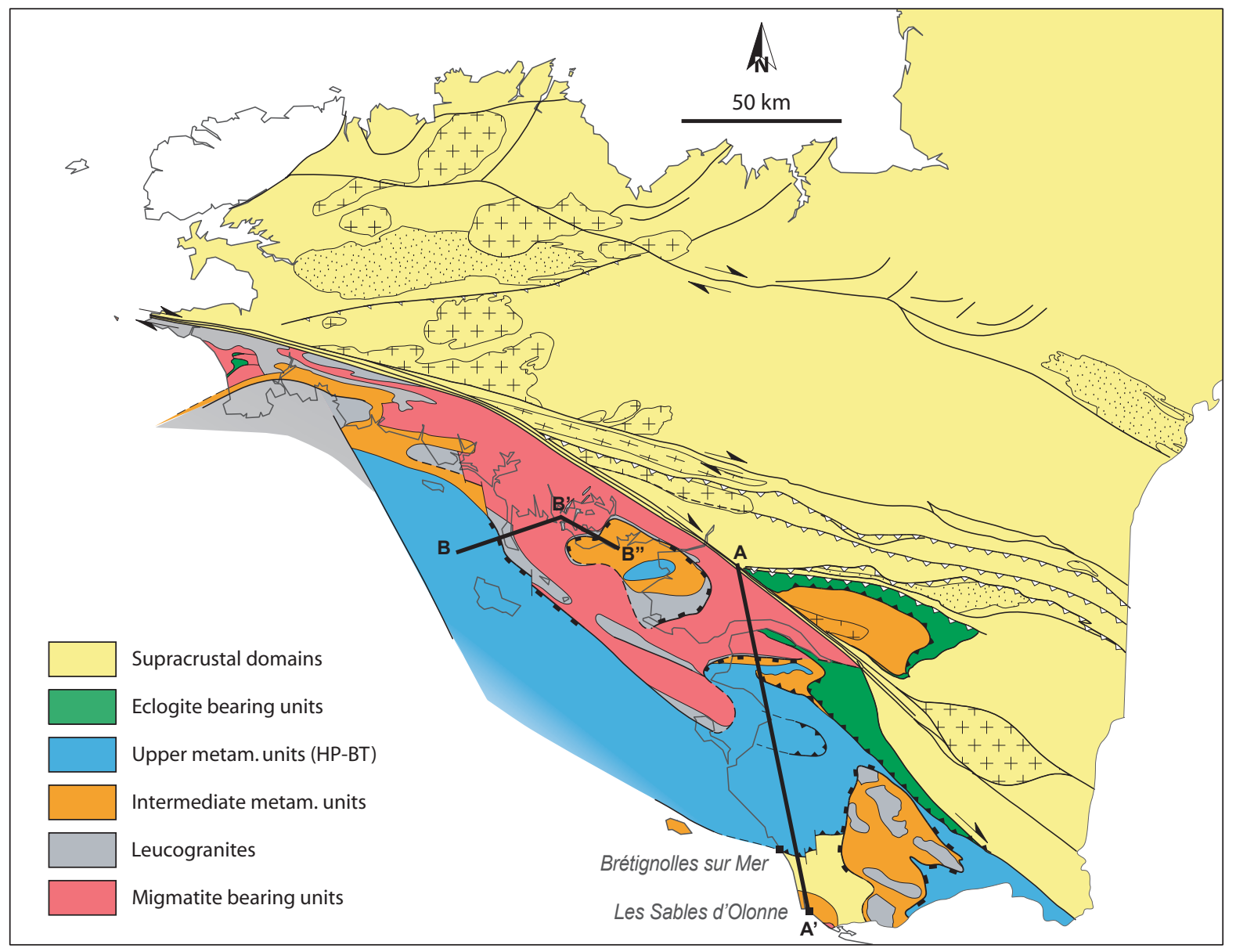

Gapais et al. - Figure 2 
a)

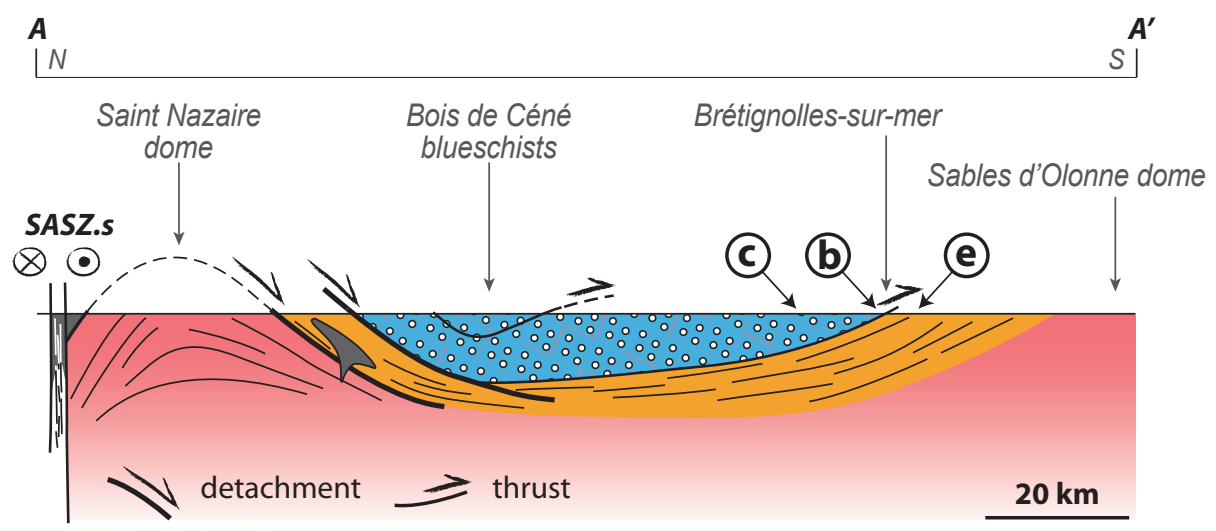

b)
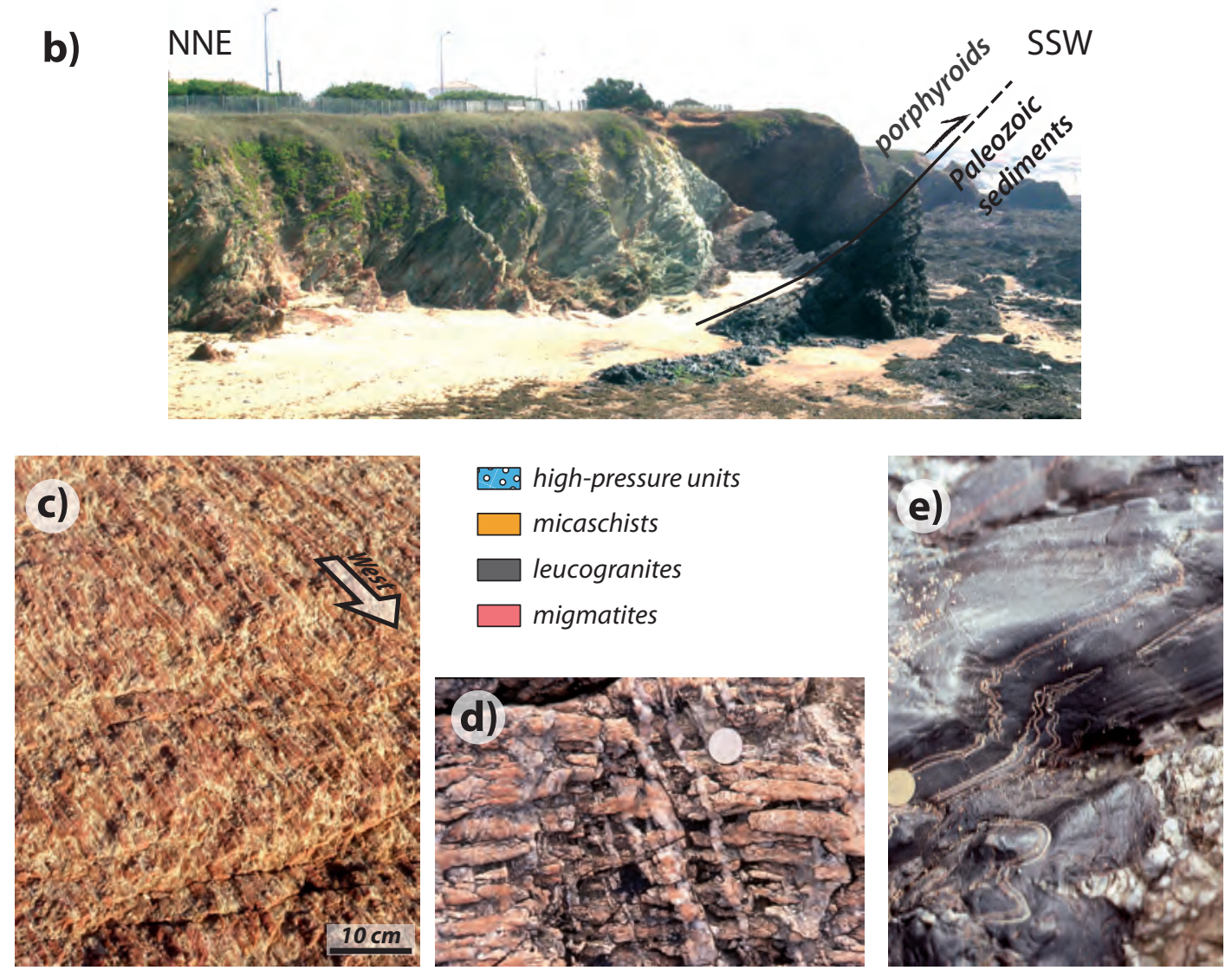

Gapais et al. - Figure 3 
a)
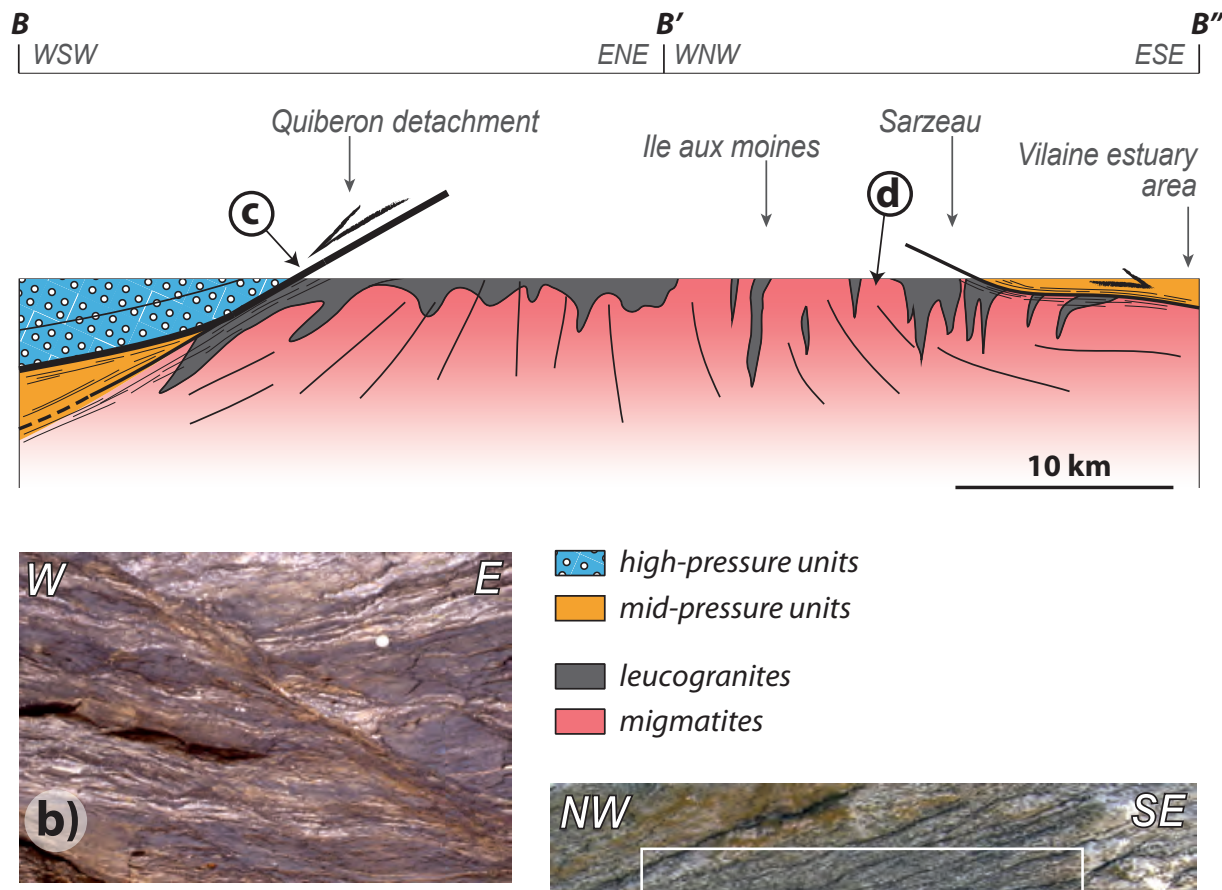

$\rightarrow$ high-pressure units

$\square$ mid-pressure units

$\square$ leucogranites

$\square$ migmatites
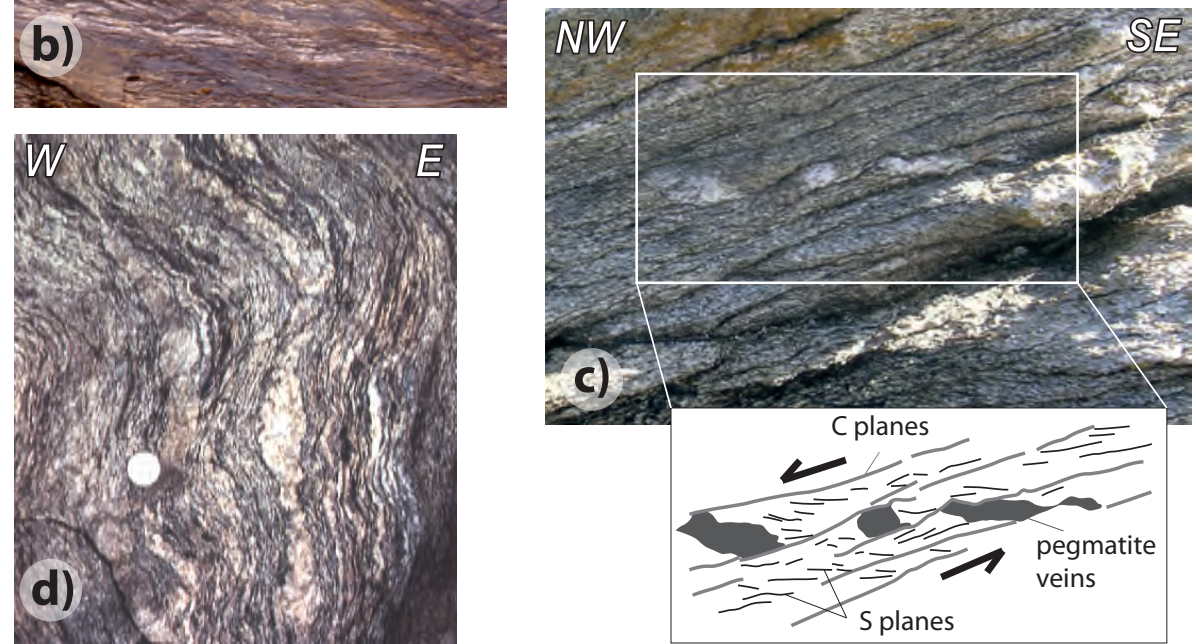

Gapais et al. - Figure 4 


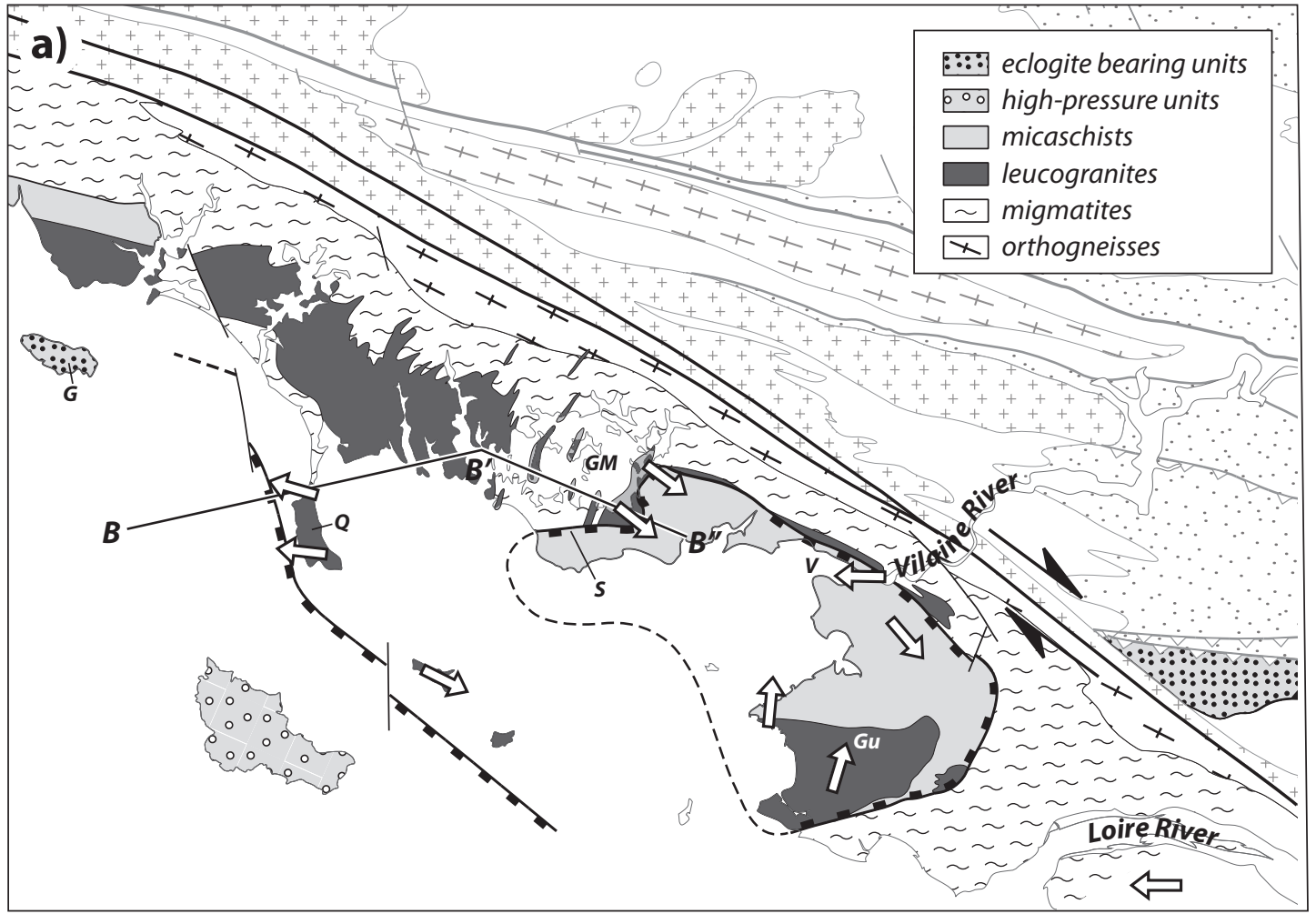

b)

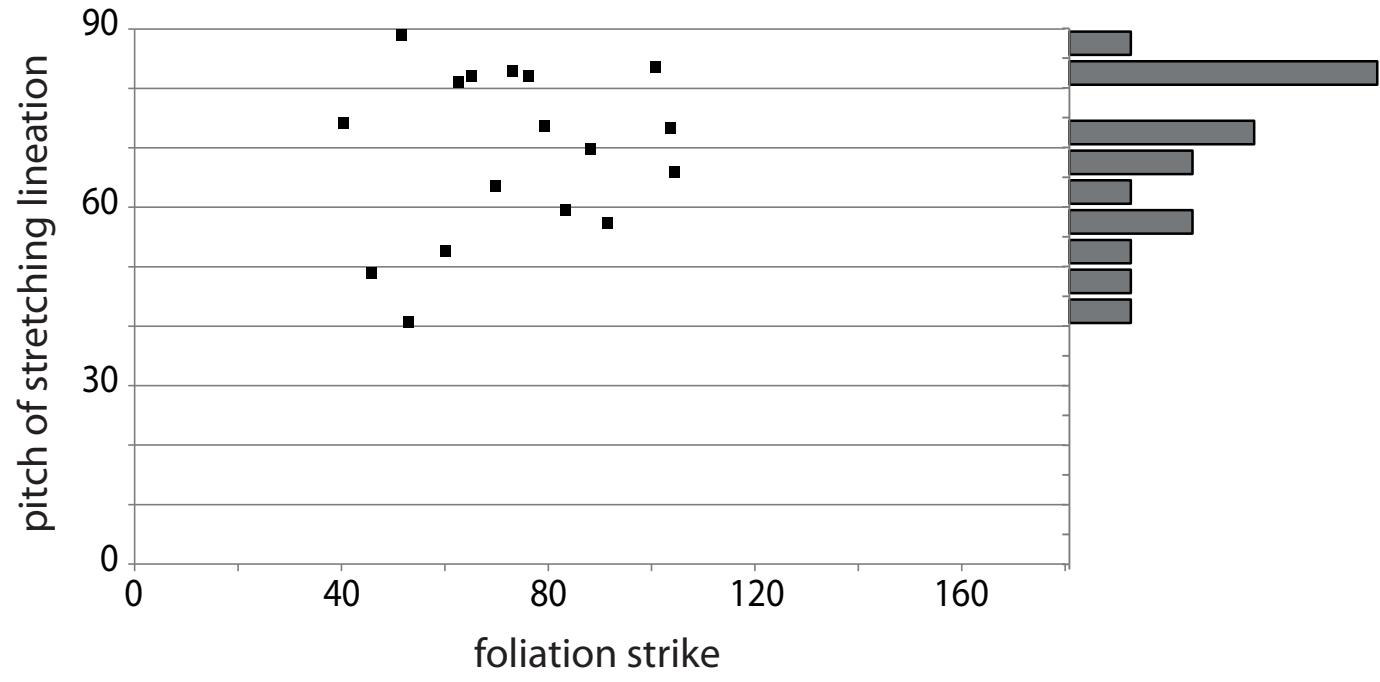

Gapais et al. - Figure 5 

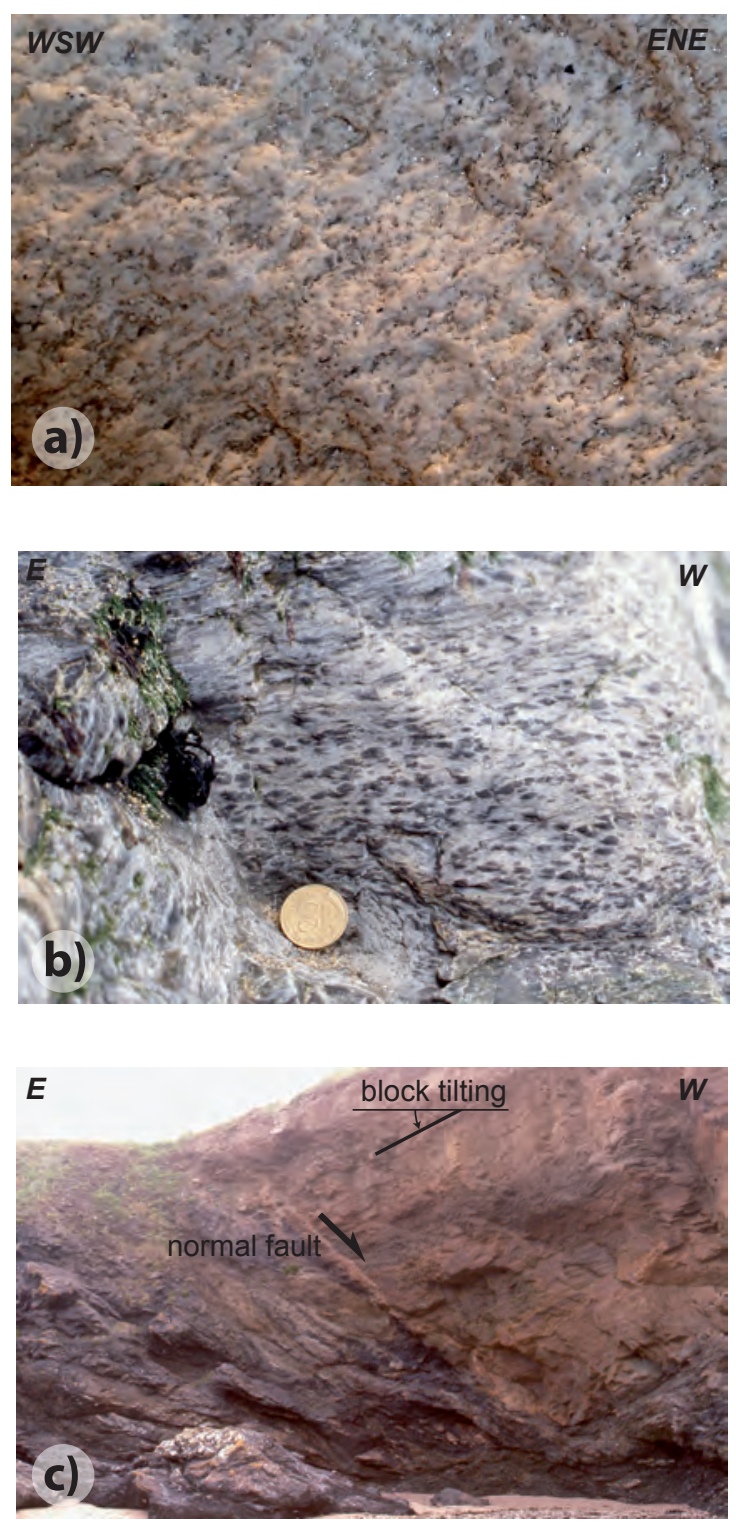

Gapais et al. - Figure 6 

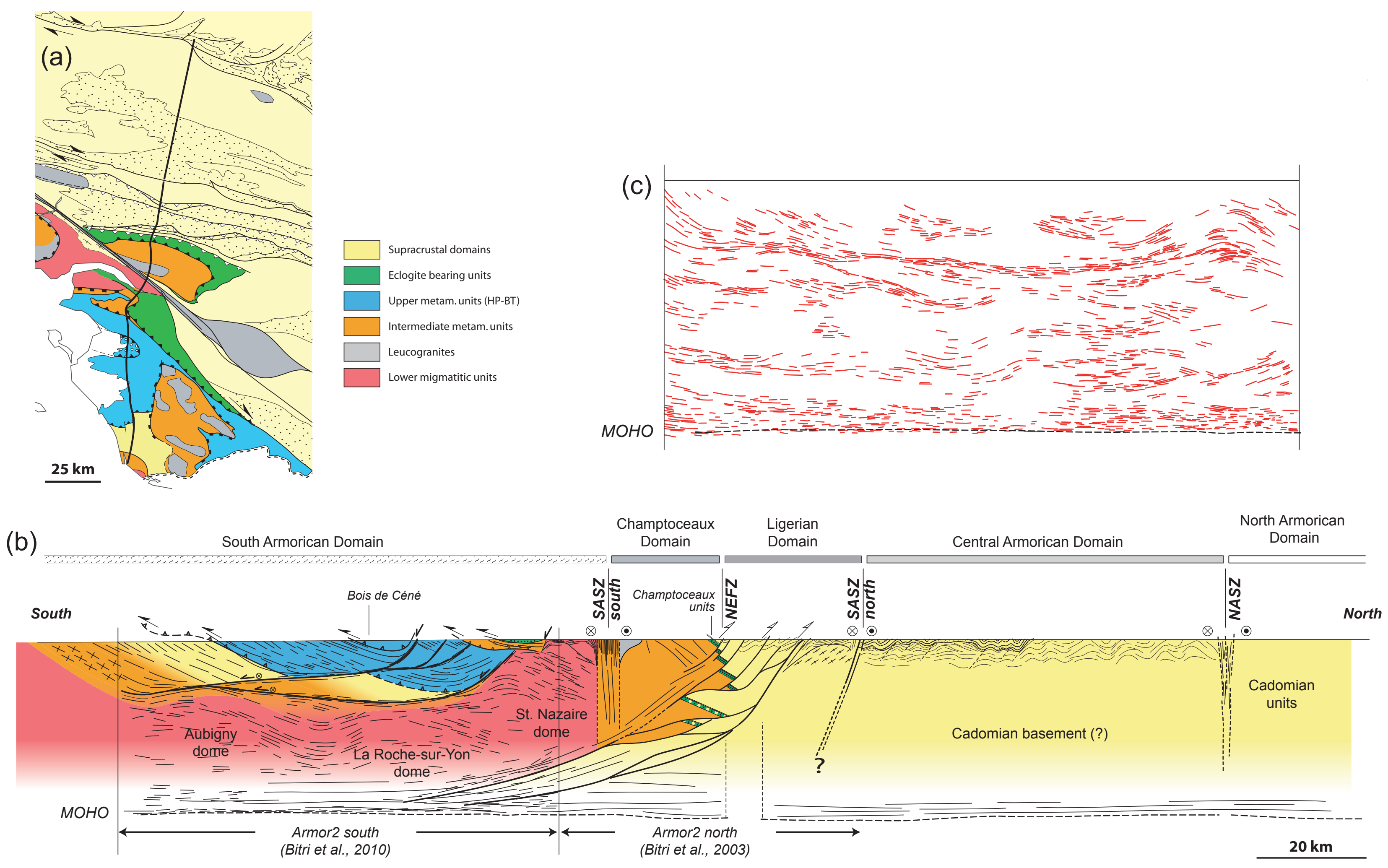
(a) Available data

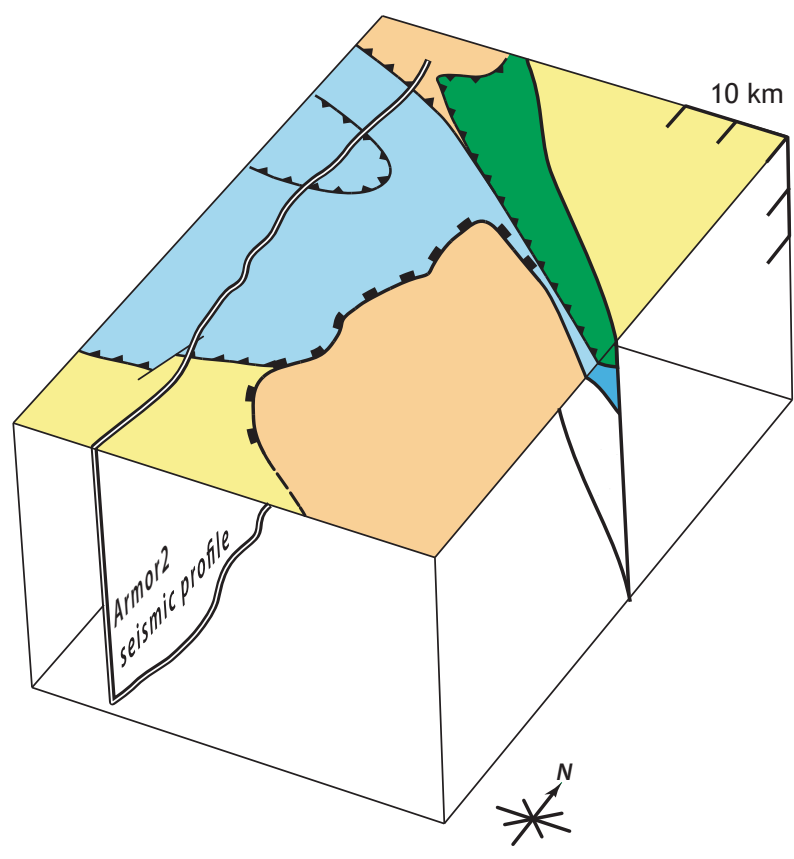

Supracrustal domains

Intermediate metam. units

Transition from supracrustal to intermediate metamorphism

Leucogranites

Lower migmatitic units

Eclogite bearing units

Upper metam. units (HP-BT) (b) Building of 3D model

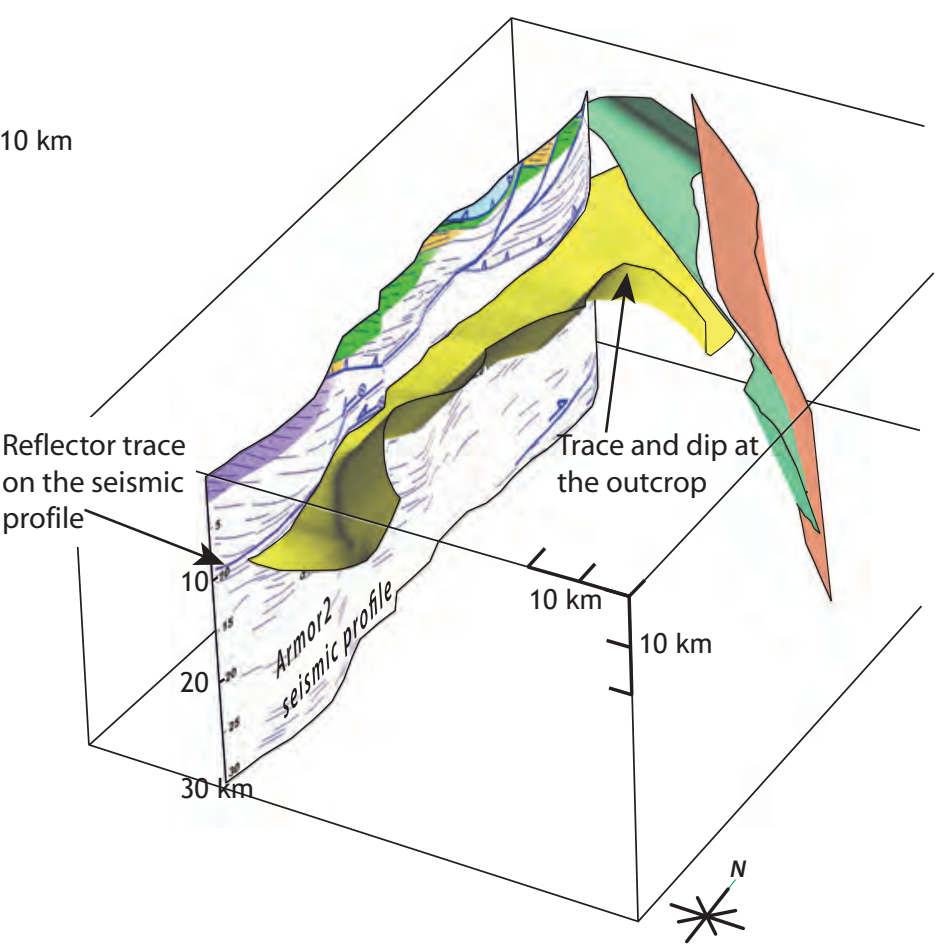

(c) Interpretative block diagram

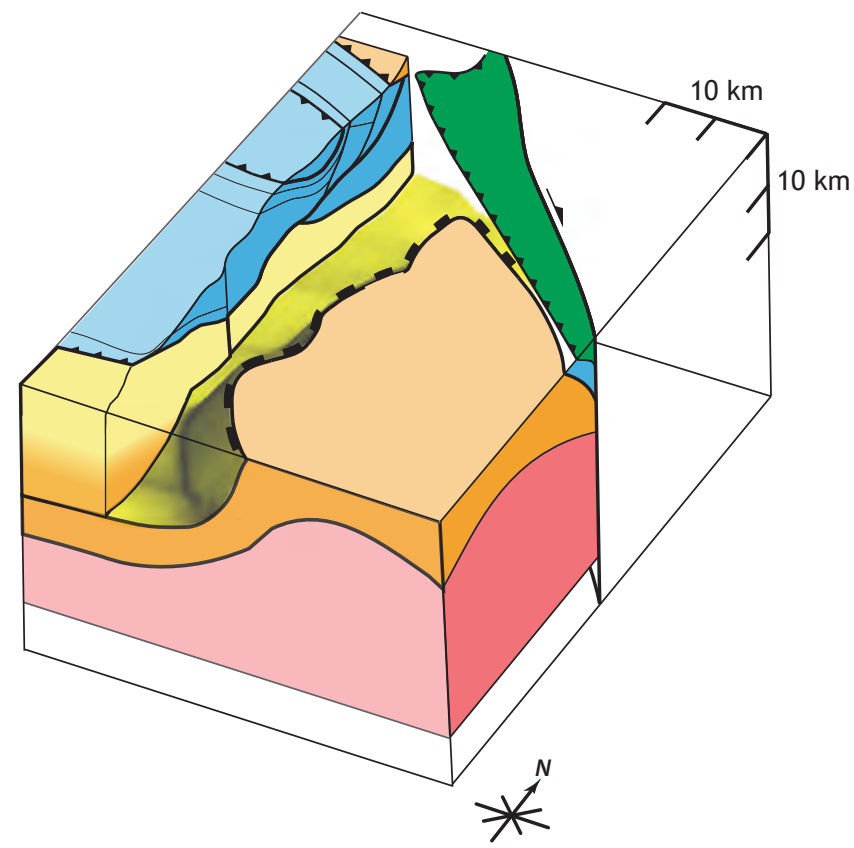



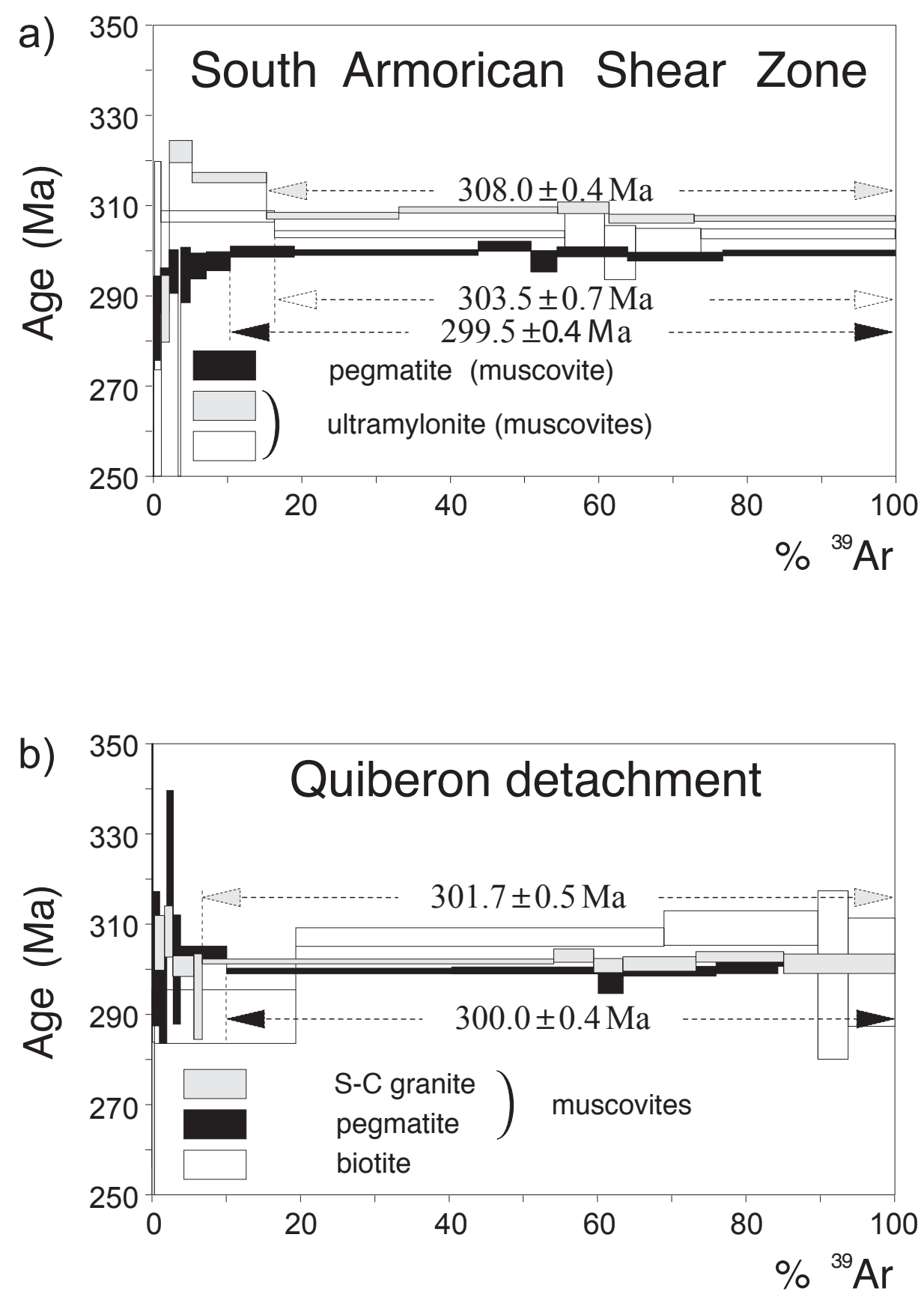

Gapais et al. Fig. 9 


\section{a) Numerical model of core complex [Tirel et al., 2008]}
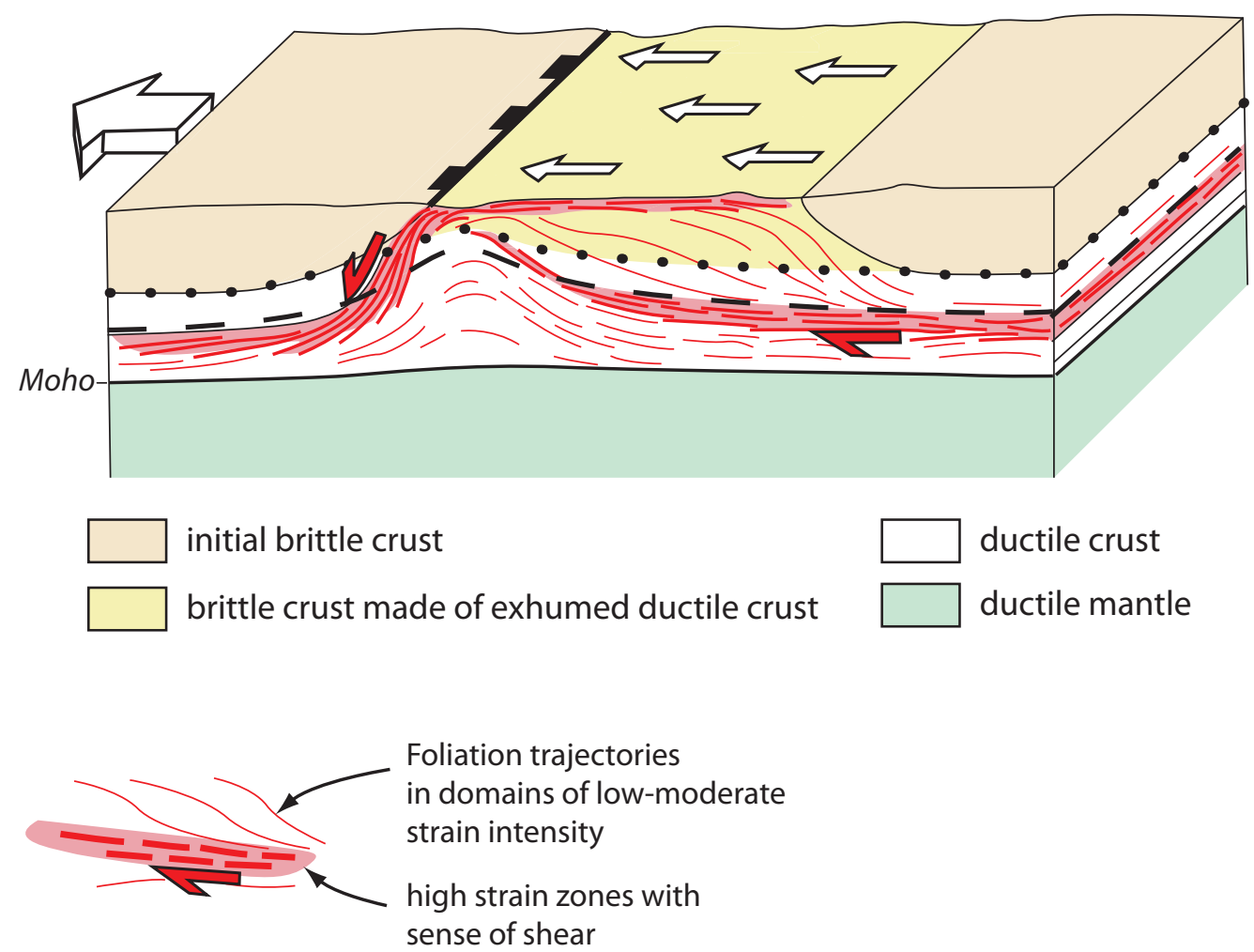

\section{b) Interpretation for South Brittany}

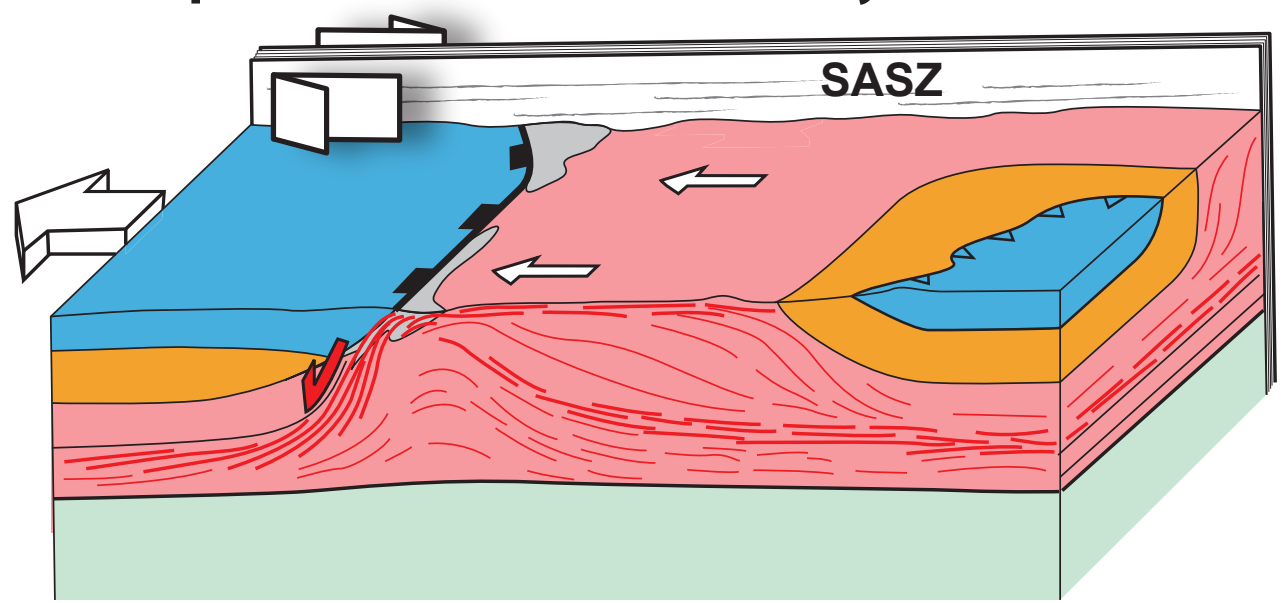

$\square$ initial brittle crust (HP and MP units)

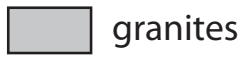

$\square$ ductile lower crust (migmatites) ductile mantle

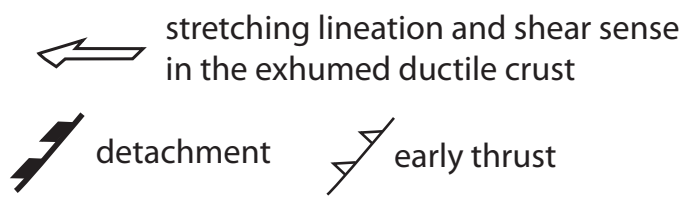

